\title{
DISTRIBUTION OF BLOOD GROUPS IN MEDICAL STUDENTS: A COMPARATIVE STUDY
}

Bishal Joshi, ${ }^{1}$ Sanjit Kumar Kar, ${ }^{1}$ Shankar Yadav, ${ }^{1}$ Prem Kumar Yadav, ${ }^{1}$ Narayan Bahadur Mahotra, ${ }^{2}$

Laxmi Shrestha, ${ }^{3}$ Amit Kumar Shrivastava ${ }^{3}$

\section{ABSTRACT}

\section{INTRODUCTION}

Blood groups depend on antigens present on the surface of red blood cells. Scientists have discovered at least 30 common antigens and hundreds of rare antigens causing antigen-antibody reaction in human red blood cells. These antigens are genetically determined and are developed in fetal life and remain unchanged till death. Many blood group systems are identified but $\mathrm{ABO}$ and $\mathrm{Rh}$ blood groups are more antigenic.

\section{MATERIAL AND METHODS}

In the present study, we observed ABO and Rh blood groups of 3057 students who studied in Universal College of Medical Sciences, Bhairahawa, Nepal from 1998 AD to 2019 AD, using open slide test method. The data was analyzed using SPSS version 20 .

\section{RESULTS}

Results of the present study indicated that the most common blood group was $\mathrm{O}(36.8 \%)$ followed by blood group $\mathrm{B}$ $(31.1 \%)$ and blood group $\mathrm{A}(24.9 \%)$ and least common blood group was $\mathrm{AB}(7.2 \%)$ i.e. $\mathrm{O}>\mathrm{B}>\mathrm{A}>\mathrm{AB}$. The same sequence of $\mathrm{ABO}$ blood grouping was seen in both male and female. Rh positive blood group was found in $95.4 \%$ and Rh negative blood group was found in $4.6 \%$ of population.

\section{CONCLUSION}

Knowledge of distribution of blood group is very important for medical students as they can serve as immediate blood donor in emergency conditions. This study can provide insight to advanced studies in future which can relate blood groups with medical conditions.

KEYWORDS ABO, Rh, Blood groups, Medical students

1. Department of Physiology, Universal College of Medical Sciences, Bhairahawa, Nepal

2. Department of Physiology, Maharajgunj Medicine Campus, IOM, TU, Kathmandu

3. Department of Pharmacology, Universal College of Medical Sciences, Bhairahawa, Nepal

DOI: http//doi.org/10.3126/jucms.v8i1.29837

\author{
For Correspondence \\ Dr. Sanjit Kumar Kar \\ Department of Physiology \\ Universal College of Medical Sciences \\ Bhairahawa, Nepal \\ Email:drkarsk@gmail.com/drkarsk@rediffmail.com
}




\section{INTRODUCTION}

$\mathrm{ABO}$ and $\mathrm{Rh}$ system of blood groups are genetically determined antigens present on the membrane of RBC. Scientists have discovered more than 30 commonly occurring antigens and hundreds of rare antigens causing antigenantibody reaction on the surface of human RBC. Most of the antigens are weak and are of very less clinical importance. Two particular groups of antigens ABO system and the Rh system are much more antigenic than the others to cause blood transfusion reactions. ${ }^{1}$ The $\mathrm{ABO}$ blood group system was discovered by Carl Landsteiner in 1901 AD. Later Landsteiner and Wiener defined the Rh blood group in Rhesus monkey in $1941 \mathrm{AD}^{2}$

On the basis of presence and absence of these antigens ABO system is divided into four major groups called $\mathrm{A}, \mathrm{B}, \mathrm{AB}$ and $\mathrm{O}$ blood groups. Likewise when D antigen is present, blood group is $\mathrm{Rh}$ positive and when $\mathrm{D}$ antigen is absent, blood group is Rh negative. ${ }^{3}$ Distribution of blood groups is important as it has multiple applications in modern medicine, anthropology, genetic research and tracing ancestral relations of humans. The knowledge of distribution of different Blood groups at various levels is very essential for fulfilling its requirement in crucial conditions. So in this study we have attempted to find out distribution of blood groups in students of Universal College of Medical Sciences, Bhairahawa, Nepal.

\section{MATERIAL AND METHODS}

This study was carried out in Department of Physiology in Universal College of Medical Sciences, Bhairahawa, Nepal. The practical sessions on determination of blood group are conducted every year in Hematology laboratory of department of Physiology for second year MBBS and BDS and first year paramedical and nursing students as per the university syllabus. The data of blood groups of the students who studied in this institute from 1998 to 2019 AD was taken from record section of Physiology department. So this complete data includes blood groups of total $3057 \mathrm{MBBS}$, BDS, paramedical and nursing students who studied in this institute in a period of 21 years. We included only Nepali and Indian students in this study. Students from other countries apart from Nepal and India were excluded in this study.

The processing and analysis of data was done from July 2019 to September 2019, after taking approval from institutional review committee (UCMS/IRC/107/19). During the practical session open slide test method ${ }^{5}$ is used for determination of blood group. For this method, we used two glass slides. These slides were divided into four parts. In four areas, one drop antiA, anti-B and anti-D and normal saline was placed separately. Subject's Blood was mixed with normal saline and RBC suspension is prepared. A drop of RBC suspension was mixed in each part with the help was dropper. The agglutination or blood clumping pattern was observed by naked eye and for confirmation the slide was observed under microscope and $\mathrm{ABO}$ blood group and $\mathrm{Rh}$ factor was determined.

\section{RESULTS}

Table 1. Distribution of ABO blood group according to Gender

\begin{tabular}{llllll}
\hline Sex & \multicolumn{5}{c}{ Blood Group } \\
& A & B & AB & O & Total \\
Male & 380 & 533 & 130 & 682 & 1725 \\
& $(22.0 \%)$ & $(30.9 \%)$ & $(7.5 \%)$ & $39.5 \%)$ & $(100.0 \%)$ \\
Female & 381 & 418 & 89 & 444 & 1332 \\
& $(28.6 \%)$ & $(31.4 \%)$ & $(6.7 \%)$ & $(33.3 \%)$ & $(100.0 \%)$ \\
Total & 761 & 951 & 219 & 1126 & 3057 \\
& $(24.9 \%)$ & $(31.1 \%)$ & $(7.2 \%)$ & $(36.8 \%)$ & $(100.0 \%)$ \\
\hline
\end{tabular}

Table 2. Distribution of $\mathbf{R h}$ blood group according to Gender

\begin{tabular}{llll}
\hline Sex & Rh-Positive & Rh-Negative & Total \\
Male & 1634 & 91 & 1725 \\
& $(94.7 \%)$ & $(5.3 \%)$ & $(100.0 \%)$ \\
Female & 1282 & 50 & 1332 \\
& $(96.2 \%)$ & $(3.8 \%)$ & $(100.0 \%)$ \\
Total & 2916 & 141 & 3057 \\
& $(95.4 \%)$ & $(4.6 \%)$ & $(100.0 \%)$ \\
\hline
\end{tabular}

Table 3. Distribution Rh Factor in A, B, AB and $\mathrm{O}$ blood groups

\begin{tabular}{lrrrrr}
\hline Blood group & A & B & AB & O & Total \\
Rh positive & 734 & 911 & 208 & 1063 & 2916 \\
& $(96.5 \%)$ & $(95.8 \%)$ & $(95.0 \%)$ & $(94.4 \%)$ & $(95.4 \%)$ \\
Rh negative & 27 & 40 & 11 & 63 & 141 \\
& $(3.5 \%)$ & $(4.2 \%)$ & $(5.0 \%)$ & $(5.6 \%)$ & $(4.6 \%)$ \\
Total & 761 & 951 & 219 & 1126 & 3057 \\
& $(100 \%)$ & $(100 \%)$ & $(100 \%)$ & $(100 \%)$ & $(100.0 \%)$ \\
\hline
\end{tabular}

The data of total 3057 medical students was analyzed using SPSS version 20. Among 3057 students, 1725 were male and 1332 were female. The most common blood group found was $\mathrm{O}(1126,36.8 \%)$ followed by blood group B $(951,31.1 \%)$ and blood group A $(761,24.9 \%)$ and least common blood group was $\mathrm{AB}(219,7.2 \%)$ i.e. $\mathrm{O}>\mathrm{B}>\mathrm{A}>\mathrm{AB}$ (Table 1). The same sequence of $\mathrm{ABO}$ blood grouping was seen in both male and female. $\mathrm{Rh}$ positive blood group was found in $95.4 \%$ and $\mathrm{Rh}$ 
negative blood group was found in $4.6 \%$ of population (Table 2 ). Among the blood groups, group $\mathrm{O}$ had highest percentage of $\mathrm{Rh}$ negative i.e. $5.6 \%$ and A blood group had lowest percentage of Rh negative i.e. $3.5 \%$ (Table 3 ). In male students $94.7 \%$ were $\mathrm{Rh}$ positive and $5.3 \%$ were $\mathrm{Rh}$ negative. In female students $96.2 \%$ were $\mathrm{Rh}$ positive and $3.8 \%$ were found to be Rh negative.

\section{DISCUSSION}

Blood groups are based on the type of antigens present on the surface of red blood cells. The gene for ABO blood group antigen is present on the long arm of ninth chromosome and $\mathrm{Rh}$ antigen is on short arm of first chromosome. ${ }^{6}$ Investigation of blood grouping is very important in relation to different diseases and is of great importance in blood transfusion and organ transplantation.?

The objective of this study is to find out the distribution of $\mathrm{ABO}$ and Rh blood groups among the medical students of Universal College of Medical Sciences (UCMS) Bhairahawa. In this study blood group of total 3057 medical students who studied in UCMS from 1998 to 2019 was analyzed. Among the total participants 2031 participants were Nepali students whereas 1026 participants were Indian students. Among all participants $1725(56.4 \%)$ were male and $1332(43.6 \%)$ were female (Table1). In present study we found that the most common blood group was $\mathrm{O}(1126,36.8 \%)$ followed by blood groups B $(951,31.1 \%)$ and $A(761,24.9 \%)$ and least common blood group was $\mathrm{AB}(219,7.2 \%)$ i.e. $\mathrm{O}>\mathrm{B}>\mathrm{A}>\mathrm{AB}$.

Many studies have been done on distribution of blood group in wide range of population across the globe. We screened for the articles in Pub Med central, Sun Direct and Google Scholar and by exclusion criteria (supplementary data 1), we found that a total of 49 articles have been published on distribution of blood group since 1964 to 2019 worldwide (Figure 1) which are similar to the present study. The aim of our study is to find out the frequency of $\mathrm{ABO}$ and $\mathrm{Rh}$ blood groups in medical students who represent population from Nepal and India. We compared the distribution of $\mathrm{ABO}$ and $\mathrm{Rh}$ blood group of present study with the similar studies done in other parts of the world (Table 4). Similar study was done by Pramanik et $\mathrm{al}^{8}$ in medical students of Kathmandu in 2000 AD.

The result of their study is slightly different from our study as the sequence of prevalence of blood group is $A>0>B>A B$. In another study done in Kathmandu valley, Pramanik et $\mathrm{al}^{9}$ found that $\mathrm{O}$ blood group was most prevalent followed by A, B and $\mathrm{AB}$ with $\mathrm{Rh}$ positive $99.2 \%$ and $\mathrm{Rh}$ negative $0.8 \%$. The differences in result between these studies and the present study may be due to the ethnic variation in population.

In similar studies, Periyavan A et $\mathrm{al}^{10}$ in Bangalore and Das PK et $\mathrm{al}^{11}$ in Vellore India found the distribution of $\mathrm{ABO}$ blood groups in sequence of $\mathrm{O}>\mathrm{B}>\mathrm{A}>\mathrm{AB}$ which is quite consistent with the present study. In other studies done in Dinajpur district of Bangladesh ${ }^{12}$, Ghana ${ }^{13}$, Uganda ${ }^{14}$, Niger-Delta ${ }^{15}$, Tanzania $^{16}$ and Saudi Arabia ${ }^{17}$ blood group O was found to be the most frequent and $\mathrm{AB}$ was found to be the least frequent which is also similar to the present study. However, in contrast to our study the sequence of distribution of blood group in their study was $\mathrm{O}>\mathrm{A}>\mathrm{B}>\mathrm{AB}$.

In similar studies conducted in Pakistan ${ }^{18}$, Khulna Medical College of Bangladesh ${ }^{19}$ and Gujarat state of India ${ }^{20}$ blood group $\mathrm{B}$ was found to be the most prevalent blood group and the sequence of distribution was $\mathrm{B}>\mathrm{O}>\mathrm{A}>\mathrm{AB}$. The result of their studies was quite different from the present study. The discrepancies found between the present study and other studies can be due to the ethnic differences among the different population of the world.

In Rh blood group system, it is well established fact that $\mathrm{Rh}$ positive blood group is highly prevalent than $\mathrm{Rh}$ negative blood group. In present study $95.4 \%$ of the participants were $\mathrm{Rh}$ positive and $4.6 \%$ were found to be Rh negative.

In a similar study in Kathmandu, Pramanik et $\mathrm{al}^{9}$ found that 99.2\% were Rh positive and only $0.8 \%$ percentage were $\mathrm{Rh}$ negative which actually shows the least prevalence of $\mathrm{Rh}$ negative blood group when compared to the other data from different areas of the World (Table 4). Whereas in a study conducted in Germany ${ }^{21}$, it was observed that $15 \%$ of the people were Rh negative which actually shows the highest percentage of $\mathrm{Rh}$ negative people in comparison to other data.

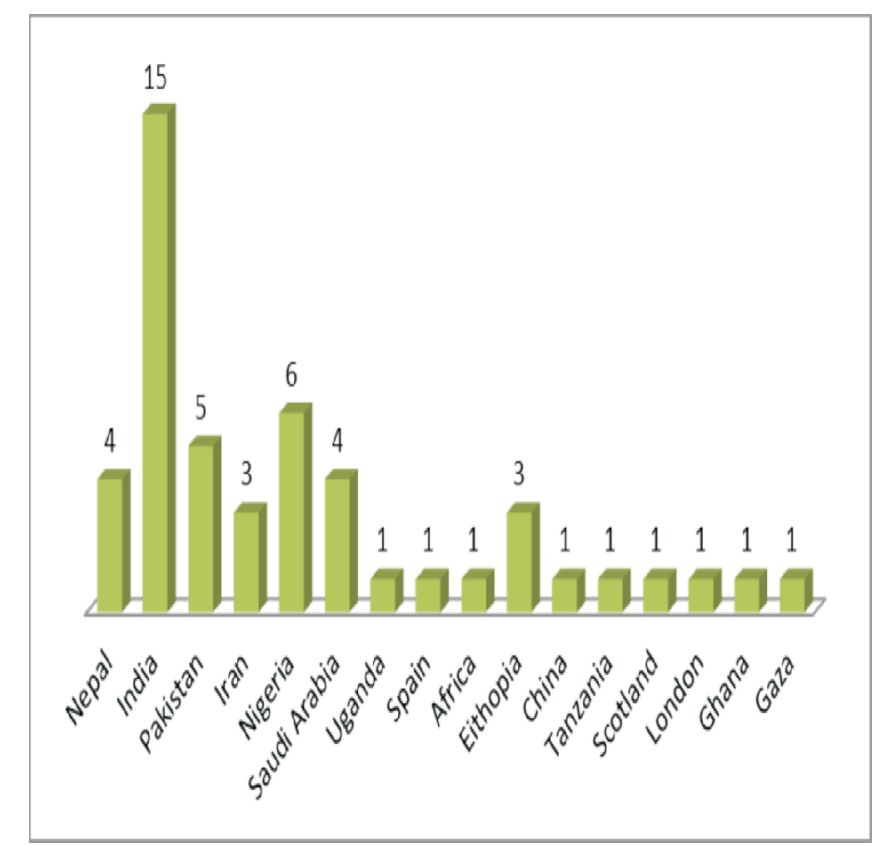


Fig 1. Number of publications in different countries Supplementary data 1

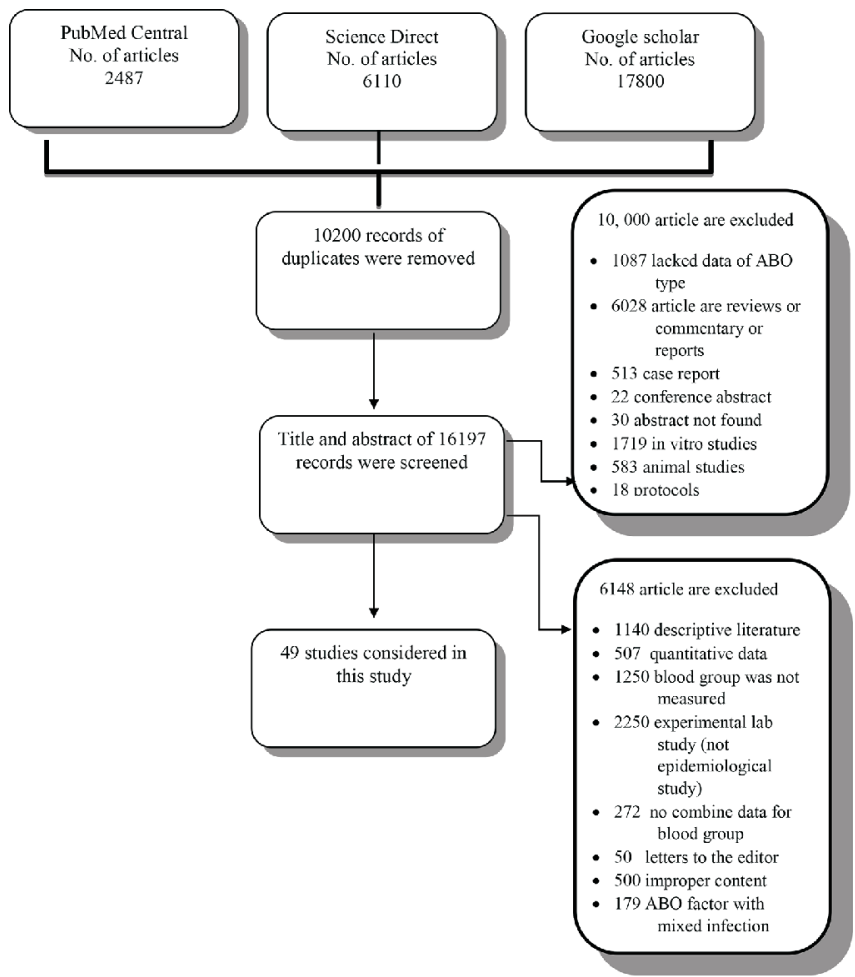

Table 4. Comparison of distribution of ABO and Rh blood group between present study and other studies

\begin{tabular}{|c|c|c|c|c|c|c|}
\hline Study done & A & B & $\mathbf{A B}$ & O & Rh Positive & Rh Negative \\
\hline Present study & 24.9 & 31.1 & 7.2 & 36.8 & 95.4 & 4.6 \\
\hline $\mathrm{Nepal}^{8}$ & 34 & 29 & 4 & 32.5 & 96.7 & 3.3 \\
\hline $\mathrm{Nepal}^{9}$ & 28.5 & 27.3 & 8.7 & 35.5 & 99.2 & 0.8 \\
\hline $\begin{array}{l}\text { Bangalore } \\
\text { (India) }^{10}\end{array}$ & 23.86 & 29.95 & 6.37 & 39.82 & 94.2 & 5.79 \\
\hline $\begin{array}{l}\text { Vellore } \\
\text { (India) }^{11}\end{array}$ & 18.85 & 33.67 & 5.27 & 42.21 & 97.3 & 2.7 \\
\hline $\begin{array}{l}\text { Bangladesh }^{12} \\
\text { (Dinajpur) }\end{array}$ & 26.6 & 23.2 & 9.6 & 40.6 & 96.8 & 3.2 \\
\hline Ghana & 24.3 & 20.7 & 5.0 & 50 & 93.8 & 6.2 \\
\hline Uganada $^{14}$ & 25.0 & 20.4 & 4.3 & 50.3 & 97.9 & 2.03 \\
\hline Niger-Delta $^{15}$ & 23.8 & 20.7 & 2.8 & 52.7 & 93.9 & 6.12 \\
\hline Tanzania & 26 & 19 & 3 & 52 & 98 & 2 \\
\hline Saudi Arabia ${ }^{17}$ & 33.4 & 6 & 3.8 & 56.8 & 92.8 & 7.2 \\
\hline Pakistan $^{18}$ & 22.91 & 35.36 & 9.32 & 32.41 & 92.03 & 7.97 \\
\hline Bangladesh $^{19}$ & 24.1 & 34.5 & 9.6 & 33 & 97.1 & 2.89 \\
\hline $\begin{array}{l}\text { Gujarat } \\
\text { (India) }^{20}\end{array}$ & 23.3 & 35.5 & 8.8 & 32.4 & 94.2 & 5.8 \\
\hline Germany $^{21}$ & 41 & 11 & 5 & 41 & 85 & 15 \\
\hline $\begin{array}{l}\text { West Iran } \\
\text { (khurdish) }\end{array}$ & 37.22 & 17.86 & 7.75 & 37.15 & 91.1 & 8.9 \\
\hline $\begin{array}{l}\text { Pakistan } \\
\text { (Peshawar) }\end{array}$ & 31.2 & 31.7 & 10.1 & 27 & 92.5 & 7.5 \\
\hline
\end{tabular}

\section{CONCLUSION}

In present study distribution of blood group in the students of Universal college of Medical Sciences was observed. The present study concludes that the most common blood group is $\mathrm{O}$ followed by $\mathrm{B}$ and $\mathrm{A}$ and least common blood group is $\mathrm{AB}$. $95.4 \%$ of the participants are Rh positive and only $4.6 \%$ are $\mathrm{Rh}$ Negative. Only few studies have been done in Nepal on blood groups and several studies are conducted in different states of India with various results. As this study includes medical students who come from several districts of Nepal and different states of India, this data represents the overall distribution of ABO and Rh blood in Nepal and India. The Knowledge about the blood group is again important in medical students because they can serve as immediate blood donors in emergency condition in hospitals.

\section{ACKNOWLEDGEMENT}

We would like to acknowledge all the members of Department of Physiology, UCMS for their cooperation and constant support during data collection. We would also like to thank all the students who studied in UCMS from 1998 to 2019 for their participation and positive attitude during practical session. We again would like to thank IRC committee UCMS for allowing us to conduct this research work.

\section{CONFLICT OF INTERESTS}

The authors declare that there is no conflict of interests.

\section{REFERENCES}

1. Kumar S, Modak PK, Ali SH, Barpanda SK, Gusain VS, Roy R. A retrospective study: $\mathrm{ABO}$ and $\mathrm{Rh}$ phenotype blood group distribution among blood donors in H.N.B. Base Hospital, Srinagar, Uttarakhand, India. J Family Med Prim Care. 2018;7:34-8.

2. Garg P, Upadhyay S, Chufal SS, Hasan Y, Tayal I. Frequency of $\mathrm{ABO}$ and Rhesus blood groups in blood donors. Journal of Clinical and Diagnostic Research. 2014 Dec;8(12):1619.

3. Fauci AS, Braunwald E, Kasper DL, Hauser SL, Longo DL, Jameson JL, Loscalzo J.Transfusion biology and therapy in: Harrison'sPrinciples of Internal Medicine 17th ed, United States of America, New York,Mc Graw Hill Medical Publishing Division: 2008;707-13.

4. Tesfaye K, Petros Y, Andargie M. Frequency distribution of $\mathrm{ABO}$ and $\mathrm{Rh}(\mathrm{D})$ blood group alleles in Silte Zone, Ethiopia. Egyptian Journal of Medical Human Genetics. 2015;16(1):716.

5. Mujahid A, Dickert F. Blood group typing: From classical strategies to the application of synthetic antibodies generated by molecular imprinting. Sensors. 2016 Jan;16(1):1-17. 
6. Webert EK, Chan HW, Smith JW, Heddle NM, Kelton JG. Red cell, platelet, and white cell antigens. In: Greer JP, Foerster J, Lukens JN, Rodgers GM, Paraskevas F, Glader B, editors. Wintrobe's clinical hematology. Philadelphia: Lippincott Williams Wilkins; 2004.p. 791.

7. Chandra T, Gupta A. Association and distribution of hypertension, obesity and $\mathrm{ABO}$ blood groups in blood donors. Iran J Pediatr Hematol Oncol. 2012;2(4):140-5.

8. Pramanik T, Pramanik S. Distribution of ABO and Rh blood groups in Nepalese medical students: a report. East Mediterr Health J. 2000 Jan; 6(1):156-8.

9. Pramanik T, Adhikari P. Trend of blood group distribution among the different ethnic groups of Kathmandu Valley. Nepal Med Coll J. 2006;8(4):248-9.

10. Periyavan A, Sangeetha SK, Marimuthu P, Manjunath BK, Seema. Distribution of $\mathrm{ABO}$ and Rhesus-D groups in and around Bangalore. Asian J Transfus Sci. 2010;4(1):41

11. Das PK, Nair SC, Harris VK, Rose D, Mammen JJ, Bose YN et al. Distribution of ABO and Rh-D blood groups among blood donors in a tertiary care centre in South India. Trop Doct. 2001;31(1):47-8

12. Talukdar SI, Das RK. Distribution of ABO and Rh blood groups among the blood donors of Dijanpur district of Bangladesh Dijanpur Medical Col J. 2010;3:55-8.

13. Doku GN, Agbozo WK, Annor RA, Kisseh GD, Owusu MA. Frequency of $\mathrm{ABO} /$ Rhesus (D) blood groupings and ethnic distribution in the Greater-Accra region of Ghana, towards effective blood bank inventory. International Journal of Immunogenetics. 2019 Apr;46(2):67-73.

14. Apecu RO, Mulogo EM, Bagenda F, Byamungu A. ABO and Rhesus (D) blood group distribution among blood donors in rural South Western Uganda: a retrospective study. BMC research notes. 2016 Dec 21;9(1):513.

15. Enosolease ME, Bazuaye GN. Distribution of ABO and Rh-D blood groups in the Benin area of Niger-Delta: Implication for regional blood transfusion. Asian J Transf Sci. 2008;2(1):35.

16. Jahanpour O, Pyuza JJ, Ntiyakunze EO, Mremi A, Shao ER. $\mathrm{ABO}$ and Rhesus blood group distribution and frequency among blood donors at Kilimanjaro Christian Medical Center, Moshi, Tanzania. BMC research notes. 2017 Dec;10(1):738.

17. Sarhan MA, Saleh KA, Bin-Dajem SM.Distribution of ABO blood groups and Rhesus factor in South West Saudi Arabia. Saudi Med J. 2009;30(1):116-19.

18. Ilyas M , Iftikhar M \& Rasheed U. Frequency of ABO and Rh Blood groups in Gujranwala (Punjab), Pakistan. Biologia (Pakistan). 2013;59(1):107-114.

19. Ahad MA, Bakar MA, Ahsan HAM. Pattern of ABO and Rhesus (Rh) blood group among blood donors. TAJ. 2002;15(2):68-70.
20. Wadhwa MK, Patel SM, Kothari DC, Pandey M, Patel DD. Distribution of ABO and Rhesus-D groups in Gujarat, India: a hospital based study. Indan J Ped Oncol. 1998;19(4):13741.

21. Pelzer U, Klein F, Bahra M, Sinn M, Dörken B, Neuhaus K, et al Blood group determinates incidence for pancreatic cancer in Germany. Front Physiol. 2013;24:118.

22. Ghobadian Z Sayemiri K, Zeinali M, Sajjadi SM. Distribution of $\mathrm{ABO}$ and $\mathrm{Rh}$ blood groups in a major ethnic group of the West Iran, the Kurdish population. Asian Journal of Medical Sciences. 2014;5(3):26-9.

23. Nazli R, Haider J, Khan MA, Akhtar T, Aslam H. Frequency of $\mathrm{ABO}$ blood groups and $\mathrm{RhD}$ factor in the female population of District Peshawar. Pak J Med Sci. 2015;31(4):984-86. 